\title{
A Comparative Study for Different Sizing of Solar PV System under Net Energy Metering Scheme at University Buildings
}

\author{
T. M. N. T. Mansur, N. H. Baharudin, R. Ali
}

School of Electrical System Engineering, Universiti Malaysia Perlis, 02600 Arau, Perlis, Malaysia

\begin{tabular}{|c|c|}
\hline Article Info & ABSTRACT \\
\hline Article history: & Malaysia has moved forward by promoting the use of renewable energy such \\
\hline Received May 22, 2018 & $\begin{array}{l}\text { as solar PV to the public to reduce dependency on fossil fuel-based energy } \\
\text { resources. Due to the concern on high electricity bill, Universiti Malaysia }\end{array}$ \\
\hline Revised Jul 20, 2018 & Perlis (UniMAP) is keen to install solar PV system as an initiative for energy \\
\hline Accepted Jul 30, 2018 & $\begin{array}{l}\text { saving program to its buildings. The objective of this paper is to technically } \\
\text { and economically evaluate the different sizing of solar PV system for }\end{array}$ \\
\hline Keywords: & $\begin{array}{l}\text { university buildings under the Net Energy Metering (NEM) scheme. The } \\
\text { study involves gathering of solar energy resource information, daily load }\end{array}$ \\
\hline Building & profile of the buildings, sizing PV array together with grid-connected \\
\hline Energy saving program & Based on the results obtained, the amount of solar energy generated and used \\
\hline Net energy metering & by the load per year is between $5.10 \%$ and $20.20 \%$ from the total annual load \\
\hline Self-consumption & demand. Almost all solar energy generated from the system will be self- \\
\hline Solar PV & $\begin{array}{l}\text { consumed by the loads. In terms of profit gained, the university could reduce } \\
\text { its electricity bill approximately between a quarter to one million ringgit per } \\
\text { annum depending on the sizing capacity. Beneficially, the university could } \\
\text { contribute to the environmental conservation by avoiding up to } 2,000 \text { tons of } \\
\mathrm{CO}_{2} \text { emission per year. }\end{array}$ \\
\hline
\end{tabular}

Copyright @ 2018 Institute of Advanced Engineering and Science. All rights reserved.

Corresponding Author:

T. M. N. T. Mansur,

School of Electrical System Engineering,

Universiti Malaysia Perlis,

02600 Arau, Perlis, Malaysia.

Email: tunkunizar@unimap.edu.my

\section{INTRODUCTION}

Malaysia has moved forward by promoting the use of renewable energy such as solar PV to the public to reduce dependency on fossil fuel based energy resources such as natural gas and coal that has been used mostly as the source of electricity generation [1]. In addition, the use of renewable energy will reduce greenhouse gas emissions to the environment that causes global warming consistent with Malaysia's commitment to the World during the $15^{\text {th }}$ Conference of the Parties (COP15) under the United Nations Framework Convention on Climate Change (UNFCCC) at Copenhagen in 2009 [2].

Starting from 2016, Malaysia has implemented the Net Energy Metering (NEM) scheme where consumers are encouraged to generate their own energy using solar PV systems. Through NEM scheme, the energy produced from the solar PV system will be consumed first by the loads, and any excess energy is exported and sold to the grid at a predetermined rate which is RM 0.31 per $\mathrm{kWh}$ for residential customers and RM 0.23 per $\mathrm{kWh}$ for commercial and industrial customers [3]. By generating their own clean energy from renewable resources, consumers could contribute to reduce the impact of environmental pollution generated by fossil fuels [4]. According to SEDA portal, the baseline $\mathrm{CO}_{2}$ for electricity generation for Peninsular of Malaysia is $0.694 \mathrm{tCO} 2 / \mathrm{MWh}$ in 2014 [5].

Due to the concern on high electricity bill, Universiti Malaysia Perlis (UniMAP) is keen to install solar PV system as an initiative for energy saving program to its buildings. Currently, a range of studies have 
been carried out to assess the performance of solar PV system for NEM scheme either for residential, commercial or industrial buildings. For example, a research has been conducted to investigate the impact of solar PV system on daily load profile and its economic feasibility. The results have shown that the grid's supply demands were significantly reduced during daytime. In addition, the investment on the system is beneficial eventhough the payback period were considered long due to the long operating life of the PV systems [6]. Another study has divided the residential into three categories which are low, medium and high energy demands. The conclusion was that the NEM implementation is profitable for high consumption consumers. Moreover, higher the consumption rate, savings are greater and consequently the payback period is less which is due to the higher cost of energy [7]. A comparative study on FiT and NEM implementation at university building was performed by Tan 2016 where he concluded that NEM scheme will reduced maximum demand and overall loads consumption of the campus [8].

Therefore the objective of this paper is to technically and economically evaluate the different sizing of solar PV system for university buildings under NEM scheme. The result may then be used by the top management to decide on the implementation.

\section{RESEARCH METHOD}

In this study, different sizings of solar PV system for university buildings under NEM scheme are designed and analyzed in terms of technical performance and profit gained. The methodology involved are gathering solar energy resource information, daily load profile of the buildings, sizing PV array together with grid-connected inverters and then lastly simulation of the designed system by using PVsyst software.

\subsection{Solar Energy Resource}

In this study, UniMAP Campus Ulu Pauh at Arau $\left(6.46{ }^{\circ} \mathrm{N}, 100.35{ }^{\circ} \mathrm{E}\right)$ which is located at the northern of Peninsular Malaysia has been chosen as the project site. The PVsyst's preloaded meteorological data obtained from Meteonorm 7.1 has provided information on solar energy at the site. There are many buildings inside the campus with various roof's tilt angles and directions faced. However, for this study roof's tilt angle of $15^{\circ}$ facing South is selected.

Figure 1 shows the monthly meteorological data for solar irradiation at tilt angle $15^{\circ}$ facing South together with average daily ambient temperature for UniMAP Campus Ulu Pauh. The total annual solar irradiation is $1,736.1 \mathrm{kWh} / \mathrm{m}^{2}$ with March has the highest irradiation which is $174.2 \mathrm{kWh} / \mathrm{m}^{2}$ while November has the lowest irradiation which is $127.0 \mathrm{kWh} / \mathrm{m}^{2}$. In addition, the annual average daily ambient temperature is $27.4{ }^{\circ} \mathrm{C}$ with March is the highest which is $28.1{ }^{\circ} \mathrm{C}$ while November is the lowest which is $26.6^{\circ} \mathrm{C}$.

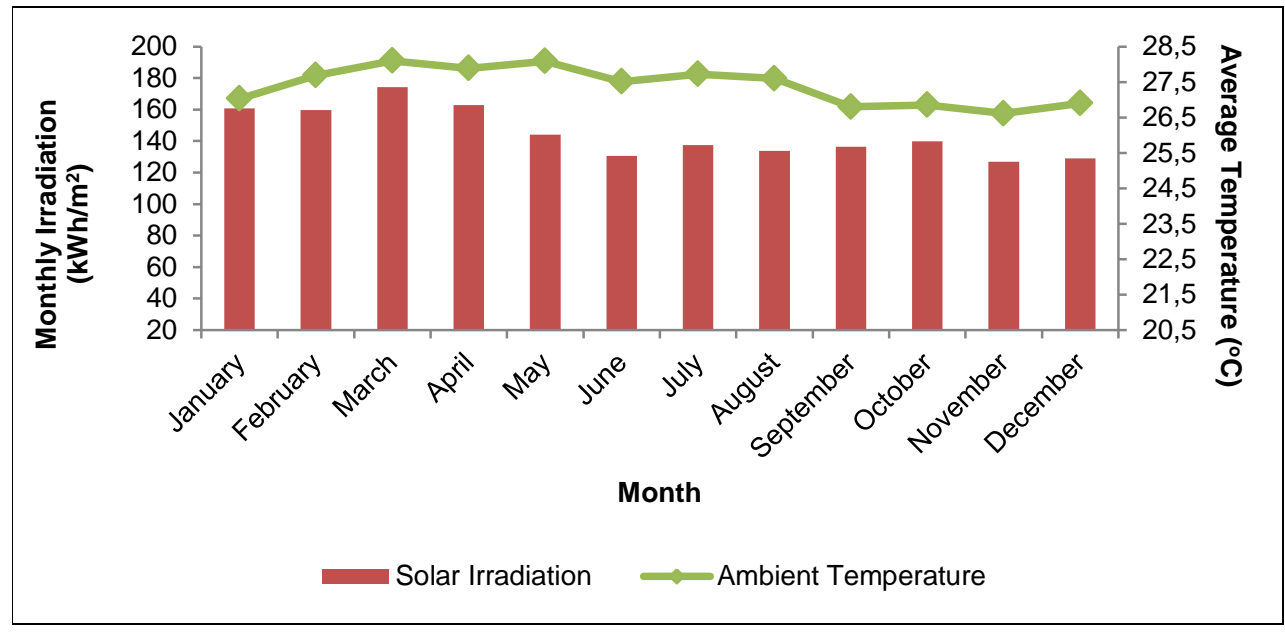

Figure 1. Monthly meteorological data for UniMAP Campus Ulu Pauh at Arau, Malaysia

\subsection{University Buildings Load Profile}

The information regarding the building's energy consumption is one of the key aspects that need to be identified and analyzed before decision is to be made in implementing the NEM system. Currently, the university is using Commercial Tariff (C1) where the tariff is at RM 0.365 per $\mathrm{kWh}$. Without NEM 
implementation, the energy consumed by the buildings is totally supplied from the grid at this tariff. However, with the implementation of NEM, some portion of the load's demand will be shared by the solar PV system which will result in a reduction of electricity bills. Comparing both grid and NEM export tariffs, it is better and profitable for the energy generated from the solar PV system to be self-consumed by the loads first, then exporting them in the event of lesser loads, because to offset the higher grid tariff price hence generating more savings.

A power monitoring device has been installed to monitor power consumption of the buildings for a week to obtain an hourly load profile data. Figure 2 shows daily load profile for the university buildings for a week at the time where the campus is fully operational. From the graphs obtained, it clearly shows two types of operations that can be distinguished according to weekday and weekend. During weekday, the power consumption is high where the average power consumed is $3,300 \mathrm{~kW}$ between 8.00 am to 5.00 pm while the highest power recorded is $3,800 \mathrm{~kW}$. In addition, the average daily energy consumed during weekday is $45,872 \mathrm{kWh}$. In contrast, the energy consumption during weekend is quite low with the average power consumption between 8.00 am until $5.00 \mathrm{pm}$ is $1,100 \mathrm{~kW}$ while the highest power recorded is only $1,260 \mathrm{~kW}$. Furthermore, the average daily energy consumed during weekend is $20,204 \mathrm{kWh}$.

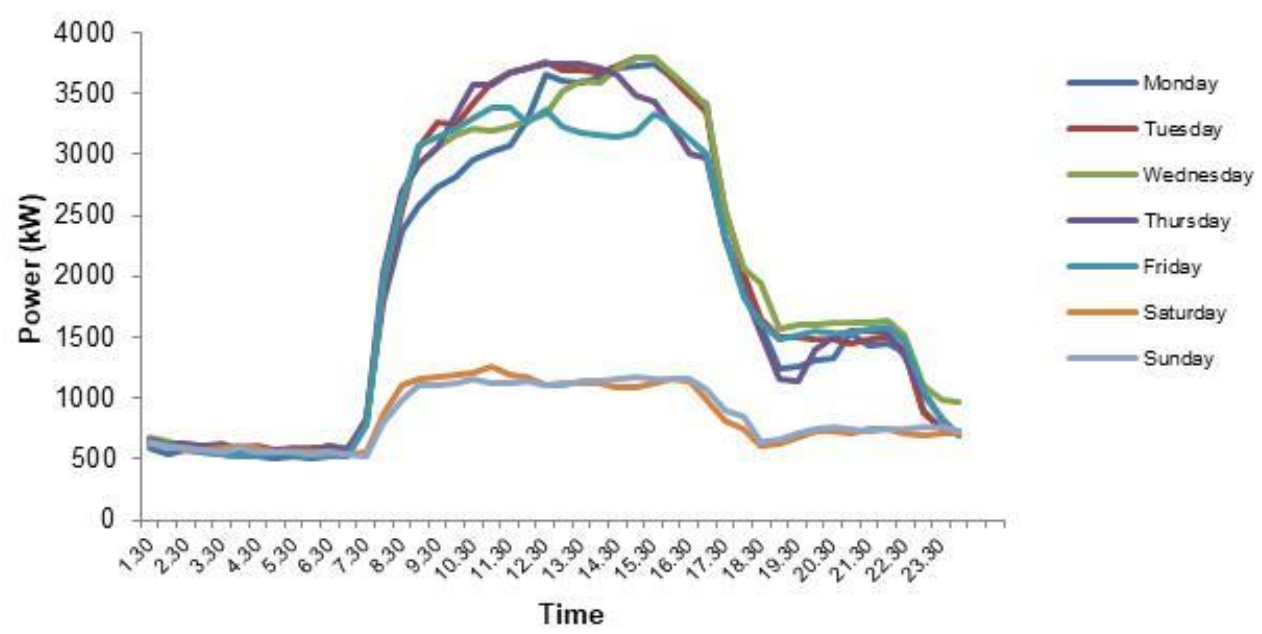

Figure 2. Daily load profile for university buildings for a week

Based on the load profile obtained, it is expected that all solar energy generated will be selfconsumed by the loads during weekday because of high demand. However some of the solar energy produced is likely to be exported to the grid during weekend especially for large solar PV capacity due to low load demand. On the other hand, the load profile obtained is during the fully operation campus and not considering periods of semester breaks or public holidays where the campus is not operating. Therefore the amount of solar energy exported to the grid is expected to rise during this period of semester breaks or public holidays.

\subsection{Performance of the System}

Performance indicators are information that shows the solar PV system's performance in a particular period such as yearly, monthly or daily. The first indicator is energy yield of the system which is calculated based on equation (1). The energy yield calculation will consider all derating factors involved [9].

$$
E_{\text {sys }}=P_{\text {array_stc }} \times P S H_{\text {period }} \times f_{\text {temp }} \times f_{m m} \times f_{\text {dirt }} \times f_{\text {age }} \times \eta_{\text {inv }} \times \eta_{\text {cable_loss }}
$$

where $P_{\text {array_stc }} P_{\text {array_stc }}$ is peak power rating of PV array at STC in kW, $P S H_{\text {period }}$ is Peak Sun Hour factor, $f_{\text {temp }}$ is temperature de-rating factor, $f_{m m}$ is power tolerance factor, $f_{\text {dirt }}$ is dirt de-rating factor, $f_{\text {age }}$ is age derating factor, $\eta_{i n v}$ is inverter efficiency and $\eta_{\text {cable_loss }}$ is cable efficiency. Energy yield value for the system could be reported as annually, monthly or daily. 
Specific yield is another performance indicator which is the amount of energy generated by the system per unit capacity. It is calculated based on equation (2).

$$
Y_{f}=\frac{E_{\text {sys }}}{P_{\text {array_stc }}}
$$

where $E_{\text {sys }}$ is amount of energy generated by the system in $\mathrm{kWh}$ while $P_{\text {array_stc }}$ is peak power rating of PV array at STC in kW. Similarly, specific yield value for the system could be reported as annually, monthly or daily. Performance ratio is a dimensionless quantity that gives the overall quality of the system. It is calculated by using equation (3).

$$
P R=\frac{E_{\text {sys }}}{E_{\text {ideal }}}
$$

where $E_{s y s}$ is amount of energy yield by the system in $\mathrm{kWh}$ while $E_{\text {ideal }}$ is ideal energy yield in $\mathrm{kWh}$ without considering derating factors.

\subsection{PV Array and Inverter Sizing}

The Yingli Solar YL250P-29b, a 250 Wp PV module and Sunny Tripower 20000TL-30, a three phase transformerless grid-connected inverter by SMA are used in this study. Selected module's specification which has been preloaded in the PVsyst database are shown in Table 1. The PV module area is $1.624 \mathrm{~m}^{2}$ per unit. Selected inverter's specification which also has been preloaded in the PVsyst database are shown in Table 2. In general, the series and parallel arrangement of PV strings must match with the inverter specification. Table 3 summarized the overall system requirement according to their capacity sizing.

Table 1. PV Module Specifications

\begin{tabular}{lc}
\hline \multicolumn{1}{c}{ Parameter } & Value at Standard Test Condition \\
& $($ STC) \\
\hline Power output, $P_{\max }$ & $250.0 \mathrm{Wp}$ \\
Voltage at $P_{\max }, V_{m p p}$ & $30.23 \mathrm{~V}$ \\
Current at $P_{\max }, I_{m p p}$ & $8.27 \mathrm{~A}$ \\
Open-circuit voltage, $V_{o c}$ & $37.73 \mathrm{~V}$ \\
Short-circuit current, $I_{s c}$ & $8.83 \mathrm{~A}$ \\
Module efficiency & $15.40 \%$ \\
Temperature coefficient at $P_{\max }, \gamma_{m p p}$ & $-0.42 \% /{ }^{\circ} \mathrm{C}$ \\
\hline
\end{tabular}

Table 2. Inverter Specifications

\begin{tabular}{lc}
\hline \multicolumn{1}{c}{ Parameter } & Value \\
\hline Input $(D C)$ & $320-800 \mathrm{~V}$ \\
MPPT voltage range & $150 \mathrm{~V}$ \\
Starting voltage & $1000 \mathrm{~V}$ \\
Maximum input voltage & 2 \\
Number of MPPT & $33 \mathrm{~A}$ \\
Maximum input current per MPPT & \\
Output $(A C)$ & $20.0 \mathrm{~kW}$ \\
Nominal output power & $400 \mathrm{~V}$, Three Phase, $50 \mathrm{~Hz}$ \\
Nominal output voltage & $98.4 \%$ \\
Maximum efficiency & \\
\hline
\end{tabular}

Table 3. System Summary

\begin{tabular}{cccccc}
\hline $\begin{array}{c}\text { Sizing Capacity } \\
(\mathrm{MWp})\end{array}$ & $\begin{array}{c}\text { No. of modules } \\
(\text { Unit })\end{array}$ & $\begin{array}{c}\text { No. of inverter } \\
(\text { Unit })\end{array}$ & $\begin{array}{c}\text { Module Area } \\
\left(\mathrm{m}^{2}\right)\end{array}$ & $\begin{array}{c}\text { Nominal PV } \\
\text { Power }(\mathrm{kW})\end{array}$ & $\begin{array}{c}\text { Nominal AC } \\
\text { Power }(\mathrm{kW})\end{array}$ \\
\hline 0.5 & 2,000 & 18 & 3,247 & 500 & 360 \\
1.0 & 4,000 & 34 & 6,494 & 1,000 & 720 \\
1.5 & 6,000 & 54 & 9,742 & 1,500 & 1,080 \\
2.0 & 8,000 & 72 & 12,989 & 2,000 & 1,440 \\
\hline
\end{tabular}




\subsection{PVsyst Simulation}

PVsyst professional software package has been developed at the University of Geneva for study, simulation, and design of PV systems [10]. PVsyst is mostly used for studying, sizing and performance analysis of photovoltaic stand alone, grid connected and water pumping systems where the results of estimation of energy yield are in close agreement with the actual measured results when measured solar radiation data of the site is used as input to the software [11]. It offers a user-friendly approach to develop a project and has a large database of meteorological data for a number of sites all over the world [12]. Figure 3 shows the PVsyst schematic diagram for NEM configuration.

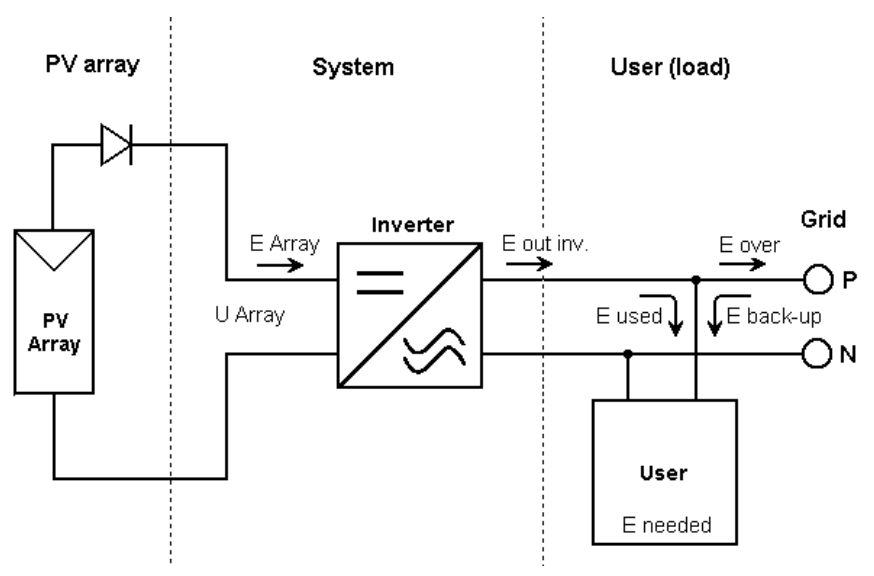

Figure 3. PVsyst schematic diagram for NEM configuration

Many researchers used PVsyst to design and simulate the performance of their PV systems either grid-connected or standalone systems by using PVsyst. For example, PVsyst software has been used to design a self-consumed solar PV DC power system for a residential house.From the results, the optimum sizing for PV array and battery bank has been obtained to meet $100 \%$ of load demand throughout the year [13] .Another research work has been carried out to analyze the performance of $100 \mathrm{kWp}$ grid connected PV system by using PVsyst for supplying the electric load of an educational institute. Based on the simulation results, the average annual performance ratio of the system is at $80 \%$ and the normalized production is 4.42 $\mathrm{kWh}$ per $\mathrm{kWp}$ daily that will provide operational benefits to the owner [14]. Another study was conducted by using PVsyst to technically and economically analyze the solar PV system for a residential house under NEM scheme. Based on the results obtained, most of the solar energy generated are exported to the grid and only up to $25 \%$ of load demand is supplied by the solar PV system [15].

\section{RESULTS AND ANALYSIS}

For this study, four different sizing capacity of solar PV systems for NEM has been designed and simulated by using PVsyst which are 0.5 MWp, 1.0 MWp, 1.5 MWp and 2.0 MWp. The technical, economic and environmental aspects of the study are presented in this section.

In terms of energy production, the amount of solar energy generated is proportional to sizing capacity as shown in Figure 4 where higher solar PV capacity will increase the energy production. From the result obtained, the solar energy generated from the system will be totally self-consumed by the loads except for the $2.0 \mathrm{MWp}$ where there is $1.1 \%$ of energy that has been exported to the grid. This is due to both loads and solar irradiance has similar profile which is peaked during day time. Since the load demand is high during daytime, most of the solar energy produced will be self-consumed. However, for the 2.0 MWp system, there is a time when solar energy exceeds the load demand such as during weekend that causing excessive energy generated to be exported to the grid. Nevertheless, in practical situation the annual exported energy is expected to be higher than the result obtained due to public or semester holidays which are not considered in this simulation. In terms of solar fraction, the amounts of solar energy generated and used by the load per year are between $5.10 \%$ and $20.20 \%$ from the total annual load demand as shown in Figure 5. 


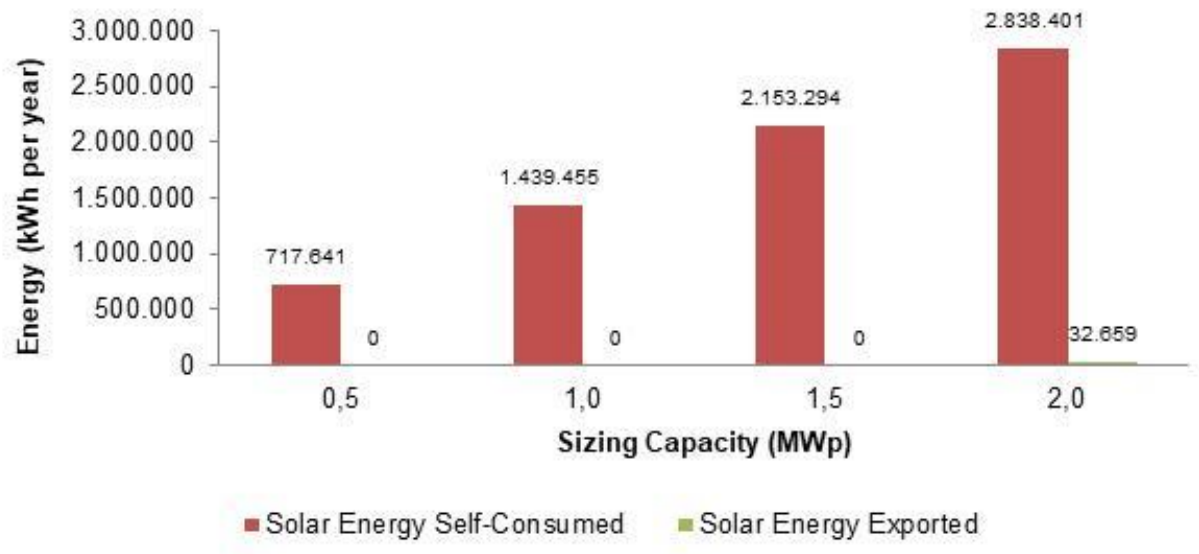

Figure 4. Annual energy production of solar PV system for NEM

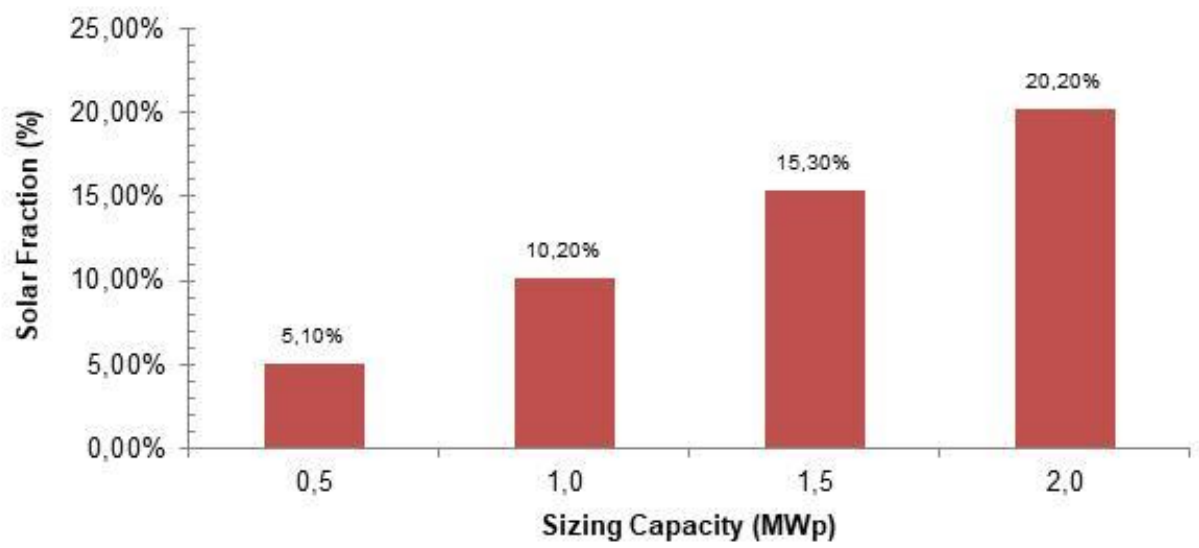

Figure 5. Percentage of annual solar fraction

Regarding the performance of the system, the annual performance ratio for all system sizing is in the region of $80 \%$ as listed in Table 4 . In addition, the specific production for all system sizing also shows good indication which is in average $1,436 \mathrm{kWh}$ per $\mathrm{kWp}$ per year or $3.93 \mathrm{kWh}$ per $\mathrm{kWp}$ per day.

Table 4. Performance of Solar PV System for NEM

\begin{tabular}{cccc}
\hline $\begin{array}{c}\text { Sizing Capacity } \\
(\mathrm{MWp})\end{array}$ & $\begin{array}{c}\text { Performance Ratio } \\
(\%)\end{array}$ & $\begin{array}{c}\text { Specific Production } \\
(\mathrm{kWh} / \mathrm{kWp} / \text { year })\end{array}$ & $\begin{array}{c}\text { Normalized Production } \\
(\mathrm{kWh} / \mathrm{kWp} / \mathrm{day})\end{array}$ \\
\hline 0.5 & 80.1 & 1,435 & 3.93 \\
1.0 & 80.3 & 1,439 & 3.94 \\
1.5 & 80.1 & 1,436 & 3.93 \\
2.0 & 80.1 & 1,436 & 3.93 \\
\hline
\end{tabular}

In terms of profit gained, the university could reduced its electricity bill by implementing NEM system, due to the self-consumed of solar energy generated and exporting excess energy to the grid. As shown in Figure 6, the amount of cost savings that could be achieved is quite high approximately between a quarter to one million ringgit per annum depending on the sizing capacity. Assuming the cost of installation of the system is RM 5,000 per kWp, the estimated payback period of the project will be around 9.5 years for all sizing capacity. 


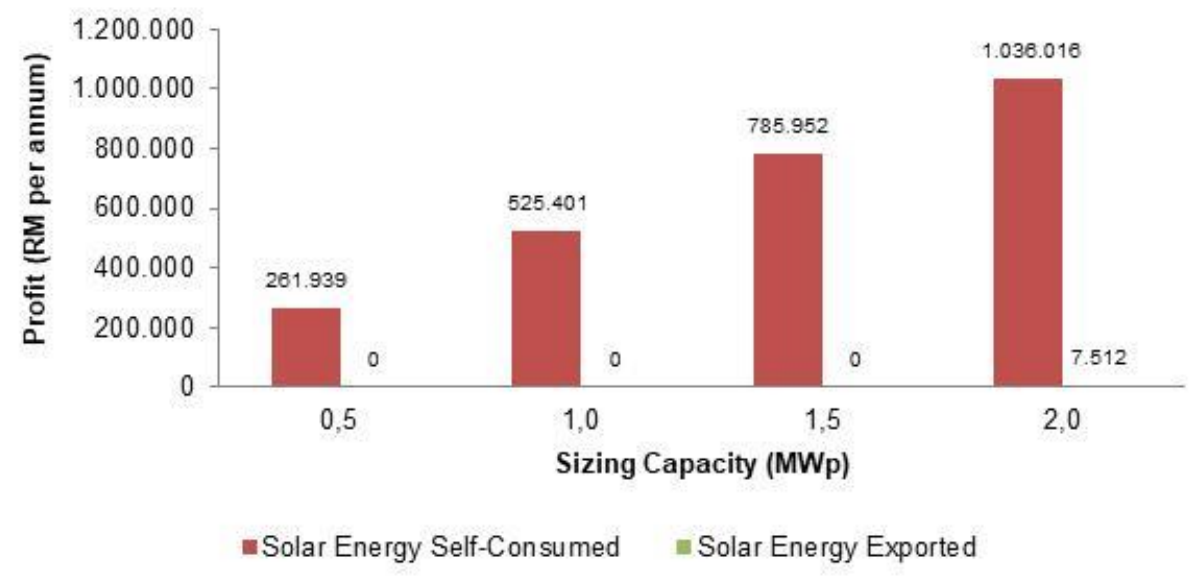

Figure 6. Annual profit gained of solar PV system for NEM

In terms of environmental conservation, this project could bring large benefit where energy produced from renewable resource and self-consumed by university buildings has replaced the fossil fuel based power from grid. As shown in Figure 7, the values of $\mathrm{CO}_{2}$ avoidance to the environment are ranged between 500 to almost 2000 tons per year depending on the sizing capacity.

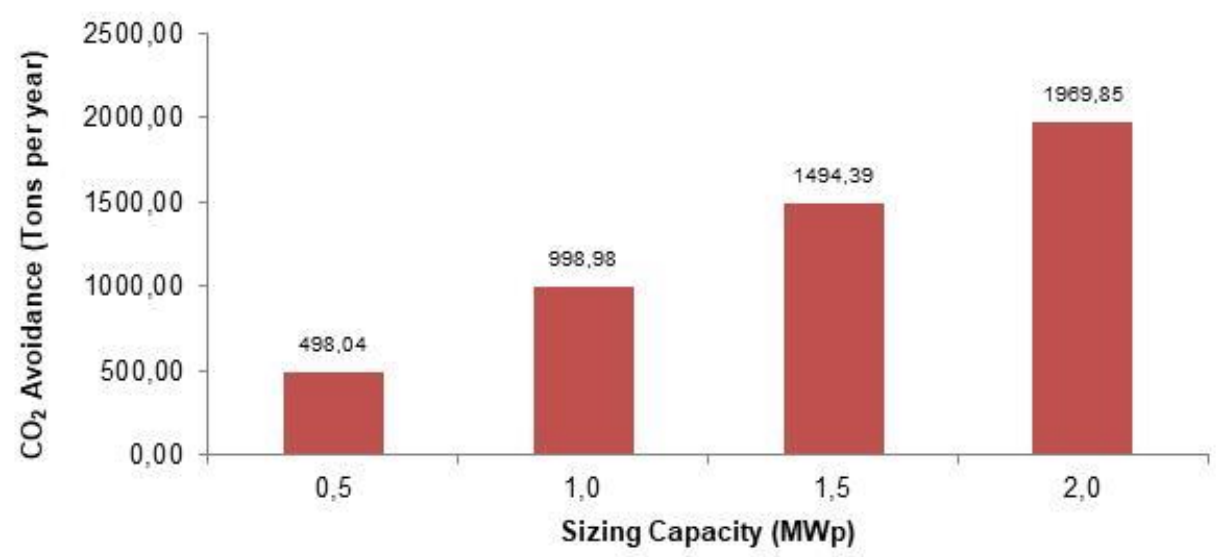

Figure 7. Annual $\mathrm{CO}_{2}$ avoidance from implementation of NEM

\section{CONCLUSION}

A comparative study for different sizing of solar PV system under Net Energy Metering scheme at university buildings has been presented in this paper. The analysis has been carried out by using PVsyst software simulation. Based on the results obtained, the conclusions were:

- In terms of energy production, higher solar PV capacity will increase the energy production. The amounts of solar energy generated and used by the load per year are between $5.10 \%$ and $20.20 \%$ from the total annual load demand. Almost all solar energy generated will be self-consumed by the loads. The system also shows good performance indication for all capacity sizing with $80 \%$ performance ratio and specific production in average $1,436 \mathrm{kWh}$ per $\mathrm{kWp}$ per year or $3.93 \mathrm{kWh}$ per $\mathrm{kWp}$ per day.

- In terms of profit gained, the university could reduce its electricity bill approximately between a quarter to one million ringgit per annum depending on the sizing capacity. Assuming the cost of installation of the system is RM 5,000 per $\mathrm{kWp}$, the estimated payback period of the project will be approximately 9.5 years for all sizing capacity.

- In terms of environmental conservation, this project could bring large benefit where energy produced from renewable resource and self-consumed by the university buildings has replaced the fossil fuel based 
power from grid. The values of $\mathrm{CO}_{2}$ avoidance to the environment are ranged between 500 to almost 2000 tons per year depending on the sizing capacity.

\section{REFERENCES}

[1] S. S. Abd Wahid, et al., "Evaluation of Residential Grid-Connected Photovoltaic System as the Potential Energy Source in Malaysia," TELKOMNIKA (Telecommunication, Computing Electronics and Control), vol/issue: 14(4), pp. $1235,2016$.

[2] C. S. Khor and G. Lalchand, "A review on sustainable power generation in Malaysia to 2030: Historical perspective, current assessment, and future strategies," Renew. Sustain. Energy Rev., vol. 29, pp. 952-960, 2014.

[3] T. M. N. T. Mansur, et al., "Design of 4. 0 kWp Solar PV System for Residential House under Net Energy Metering Scheme," J. Eng. Res. Educ., vol. 9, pp. 95-106, 2017.

[4] R. Setiabudy, et al., "Analysis characteristics of on/offgrid tie inverter and implementation in microgrid," TELKOMNIKA (Telecommunication, Computing Electronics and Control), vol/issue: 11(3), pp. 441-450, 2013.

[5] "Statistic \& Monitoring CO2 Avoidance," Sustainable Energy Development Authority (SEDA) Malaysia Portal, 2017. Available: www.seda.gov.my.

[6] J. T. Dellosa, "Financial payback of solar PV systems and analysis of the potential impact of net-metering in Butuan City, Philippines," 2015 IEEE 15th Int. Conf. Environ. Electr. Eng. EEEIC 2015 - Conf. Proc., pp. 1453$1458,2015$.

[7] M. S. Sree, et al., "Feasibility study for the net metering implementation in residential solar PV installations across Tamil Nadu," 2014 Int. Conf. Comput. Power, Energy, Inf. Commun. ICCPEIC 2014, pp. 359-362, 2014.

[8] R. H. G. Tan and T. L. Chow, "A Comparative Study of Feed in Tariff and Net Metering for UCSI University North Wing Campus with 100 kW Solar Photovoltaic System,” Energy Procedia, vol. 100, pp. 86-91, 2016.

[9] A. M. Omar, et al., "Grid-Connected Photovoltaic Power Systems Design," Sustainable Energy Development Authority Malaysia, 2012.

[10] M. Bouzguenda, et al., "Design of an Off-Grid 2 kW Solar PV System," 2014 9th International Conference on Ecological Vehicles and Renewable Energies, EVER 2014, pp. 1-6, 2014.

[11] V. Sharma and S. S. Chandel, "Performance analysis of a $190 \mathrm{kWp}$ grid interactive solar photovoltaic power plant in India," Energy, vol. 55, pp. 476-485, 2013.

[12] P. Yadav, "Simulation and Performance Analysis of a lkWp Photovoltaic System Using PVsyst," pp. 358-363, 2015.

[13] T. M. N. T. Mansur, et al., "Performance Analysis of Self-Consumed Solar PV System for A Fully DC Residential House," Indones. J. Electr. Eng. Comput. Sci., vol/issue: 8(2), pp. 391-398, 2017.

[14] N. M. Kumar, et al., "Performance analysis of $100 \mathrm{kWp}$ grid connected Si-poly photovoltaic system using PVsyst simulation tool," Energy Procedia, vol. 117, pp. 180-189, 2017.

[15] T. M. N. T. Mansur, et al., "Technical and Economic Analysis of Net Energy Metering for Residential House," Indones. J. Electr. Eng. Comput. Sci., vol/issue: 11(2), pp. 585-592, 2018. 